\title{
Substrate Selection of Ascidian Larva: Wettability and Nano-Structures
}

\author{
Euichi Hirose $^{1, *(D)}$ and Noburu Sensui ${ }^{2}$ \\ 1 Department of Chemistry, Biology and Marine Science, Faculty of Science, University of the Ryukyus, \\ Nishihara, Okinawa 903-0213, Japan \\ 2 Department of Human Biology and Anatomy, Graduate School of Medicine, University of the Ryukyus, \\ Nishihara, Okinawa 903-0215, Japan; sensuiso@med.u-ryukyu.ac.jp \\ * Correspondence: euichi@sci.u-ryukyu.ac.jp
}

check for

updates

Citation: Hirose, E.; Sensui, N Substrate Selection of Ascidian Larva: Wettability and Nano-Structures. J. Mar. Sci. Eng. 2021, 9, 634. https:// doi.org/10.3390/jmse9060634

Academic Editor: Francesca Cima

Received: 19 May 2021

Accepted: 4 June 2021

Published: 7 June 2021

Publisher's Note: MDPI stays neutral with regard to jurisdictional claims in published maps and institutional affiliations.

Copyright: (c) 2021 by the authors. Licensee MDPI, Basel, Switzerland. This article is an open access article distributed under the terms and conditions of the Creative Commons Attribution (CC BY) license (https:/ / creativecommons.org/licenses/by/ $4.0 /)$.

\begin{abstract}
Ascidians are marine sessile chordates that comprise one of the major benthic animal groups in marine ecosystems. They sometimes cause biofouling problems on artificial structures underwater, and non-indigenous, invasive ascidian species can potentially and seriously alter native faunal communities. Ascidian larvae are usually tadpole-shaped, negatively phototactic, and adhere on substrates by secreting a glue from their adhesive organs. Although larvae often prefer hydrophobic surfaces, such as a silicone rubber, for settlement, hydrophobic materials are often used to reduce occurrence of fouling organisms on artificial structures. This inconsistency may indicate that an attractive surface for larvae is not always suitable for settlement. Micro-scale structures or roughness may enhance the settlement of ascidian larvae, but settlement is significantly reduced by a nano-scale nipple array (or moth-eye structure), suggesting functional properties of similar structures found on the body surfaces of various invertebrates. The substrate preferences of larvae should be one of the important bases in considering measures against biofouling, and this review also discusses the potential uses of materials to safely reduce the impacts of invasive species.
\end{abstract}

Keywords: biofouling; larval settlement; substrate preference; water wettability; moth-eye structure; MOSMITE $^{\mathrm{TM}}$; silicone paradox

\section{Introduction}

In nature, sessile organisms are usually distributed unevenly on substrates, suggesting the occurrence of selection. We can consider two selection processes; pre-settlement selection and post-settlement selection. The former is substrate selection for settlement by the mobile phase of settlers, such as larvae. The larvae may carefully select the microhabitat and the substrate material for settlement to have better conditions for survival, using their sensory systems. The present review mainly focuses on this pre-settlement selection. When a larva settles on an unfavorable site, post-settlement selection brings about death or ejection of the settlers from the site. This post-settlement selection is induced by not only physical and chemical factors but also via biological interactions such as inter- and intra-specific competitions.

Substrate selection by larvae has been assessed by both field and laboratory experiments. In field experiments, test substrata are immersed in the field and the amounts of settlers are compared among the substrata under different conditions [1,2]. Results include both pre-settlement selection and post-settlement selection. Laboratory experiments are mainly carried out to examine particular factor(s), such as texture, wettability, or color of substrata, on pre-settlement selection, but as results do not always reflect the natural settlement process, care should be taken in interpreting these results. These experiments can be subdivided into single-choice [3-6], dual-choice [7,8], and multi-choice tests [9-11]. In an example single-choice test, the inner wall of a container was entirely coated with a test substrate and the rate of metamorphosis/settlement of larvae was compared among 
substrate types. Therefore, larval preferences among the substrates are not directly assessed in this method. In dual- and multi-choice tests, two or more substrates are placed in a container, and the number of settlers or selection indices are compared among the substrates. However, it is difficult to assess the larval preferences for substrates, as larvae often select the inner wall(s) of a container, and thus, the substrate may not be the only assay. We can prevent larval settlement on a container wall by coating with a less preferred material. For instance, ascidian larvae rarely settle on substrates coated with $1.5 \%$ agar [12].

The substrate preference of larvae is an important key for controlling larval settlement and for better understanding of evolutionary adaptations in pre-settlement selection. Management of biofouling has been paid great attention, particularly with regards to aquaculture facilities and ship hulls, because of the serious economic losses caused by fouling [13]. Although anti-fouling compounds have been developed and used in coatings to reduce biofouling [14], the massive use of bioactive compounds for settlers may carry a risk of pollution to aquatic ecosystems [15]. The physical properties of a substrate surface, such as structure and wettability, also affect the substrate preferences of settlers. In contrast to chemical approaches, countermeasures based on physical properties may be less effective for settlers but more eco-friendly. To develop such physical approaches against biofouling, it is necessary to elucidate the larval preference(s) of the physical properties of substrates for settlement. This review focuses on wettability and nano-structures of substrate surfaces for the substrate selection of ascidian larvae, while other factors of microhabitat influencing the pre-settlement selection were examined, such as the orientation of the substrate (i.e., vertical or horizontal) [2], nutrient contaminants in water [16], and textures of the substrate [9].

\section{Ascidians and Their Larvae}

Ascidians are the only sessile group among the extant chordates. They are one of the major benthic animal groups and are suspension feeders in marine ecosystems [17]. Some ascidians are solitary in form throughout their life, and some form colonies following asexual budding. Ascidian species comprise the class Ascidiacea belonging to the subphylum Tunicata (or Urochordata). One of the unique characters of tunicates is biosynthesis of cellulose, and the tunic in ascidians is the cellulosic matrix entirely covering the epidermis and forming an integumentary matrix [18]. Therefore, ascidians always adhere to the substrate via the tunic.

The morphology of ascidians and their larvae were described in detail by Burighel and Cloney [19]. Briefly, ascidian larvae are usually tadpole-shaped and composed of a tail and trunk; the tail has a notochord and muscles that produce swimming force, and the trunk has rudimentary juvenile organs, a sensory vesicle containing a pigmented otolith and/or photolith, and adhesive organs (Figure 1). The larval body is entirely covered by the tunic. Whereas some species produce tail-less larvae through direct development, phylogenetic analyses have shown that this is an apomorphic character [20]. The larva is supposed to sense gravity and light with the otolith and photolith, respectively. By means of laser ablation of the otolith and photolith, Tsuda et al. [21] demonstrated that upward swimming occurs due to negative geotaxis in the initial period of the larval stage, and then, negative phototaxis occurs in the latter period. This upward swimming probably aids in the dispersal of drifting larvae, and negative phototaxis results in larval settlement in shaded sites. Ascidians, particularly juveniles, are vulnerable to ultraviolet (UV) radiation [22], and thus, the light sensitivity of larvae has an important role in selecting the habitat environment in species inhabiting shallow waters. Ascidian larvae usually have three adhesive organs at the apical end of the trunk (arrowheads in Figure 1a), and adhesive compounds containing glycoprotein, sugar residues, and catechol residues are secreted from the collocytes [10]. The adhesive organs also perform a sensory function, and some collocytes are supposed to be evolutionarily derived from neurosecretory cells [23]. Therefore, this organ should play an important part in substrate selection for settlement, sensing surface structures, wettability, and other properties. Following adhesion to the substrate by adhesive secretion, 
metamorphosing larvae absorb the tail into the trunk (Figure 1b), and extend epidermal ampullae to hold fast to the substrate (arrows in Figure 1c).
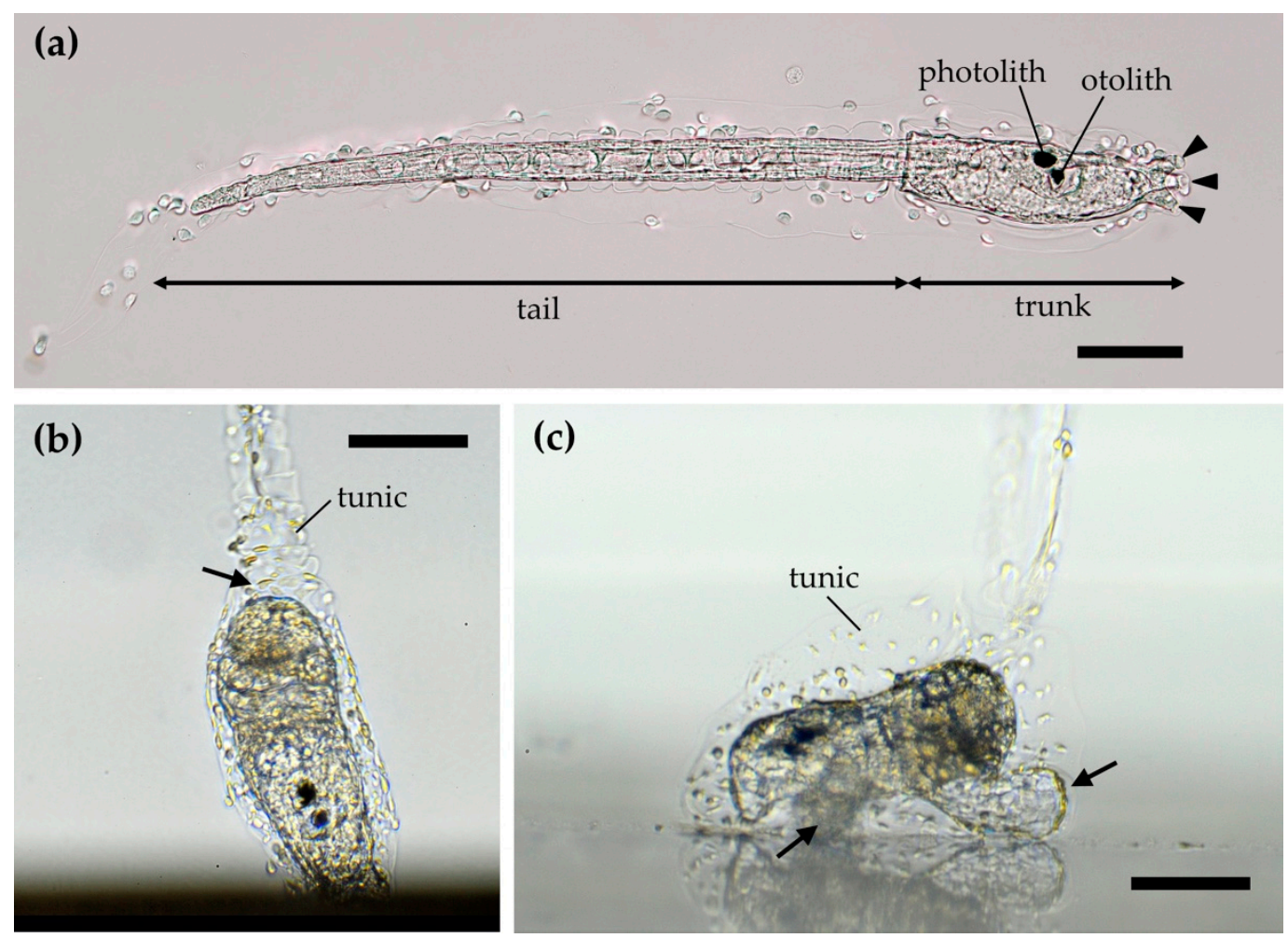

Figure 1. Swimming larva (a) and the settlement (b,c) of Phallusia philippinensis (lateral view). (a) A swimming larva with a tail. Three adhesive organs are present at the apical end of the trunk (arrowheads). (b) A larva adhering to the substrate with the adhesive organs. The tail is absorbed into the trunk (arrow). (c) A metamorphosing larva extending epidermal ampullae onto the substrate (arrows). All scale bars indicate $100 \mu \mathrm{m}$.

Natural chemical cues for settlement are known in various marine organisms, and many studies have reported on various natural products that affect the settlement and metamorphosis of larvae [24]. In the ascidian Halocynthia roretzi, a metamorphosis-inducing substance was isolated from the larvae, the larval-conditioned seawater, and the adult tunic [25], although the working mechanism of this substance is still uncertain. In the colonial ascidian Botryllus schlosseri, larvae may recognize their kin and aggregately settle with genetically related individuals [26].

\section{Water Wettability}

\subsection{Measurement of Wettability}

Water wettability is generally quantified as the contact angle of a water droplet on the surface. The angle is smaller on more hydrophilic surfaces and larger on more hydrophobic surfaces (Figure 2a). Whereas the contact angle is usually measured in the air, water wettability can be measured in the water as the contact angle of an air bubble (Figure 2b). In this case, the contact angle of a bubble is smaller on more hydrophobic surfaces. To evaluate the surface wettability of substrates, the contact angle of a bubble in seawater is better than the contact angle of a water droplet in the air, as the settlement of marine organisms usually occurs in the seawater. In the same manner, oil wettability (lipophilicity/lipophobicity) can be measured as the contact angle of an oil droplet (Figure 2c). High water wettability means low air wettability, and thus, air bubbles are rarely attached on hydrophilic substrates in water. Accordingly, when we find an object on which many bubbles are attached in shallow water, it likely has a hydrophobic surface. 

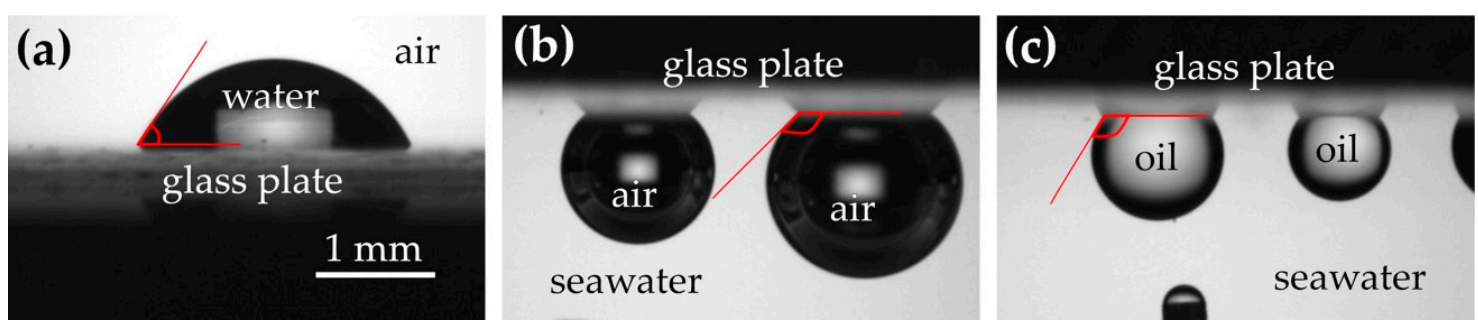

Figure 2. Contact angles (red lines) of a water droplet (a), air bubbles (b), and oil droplets (c) on a glass plate (cover slip).

However, natural objects with many bubbles are rarely encountered in shallow waters, indicating that many natural objects in the water usually have hydrophilic surfaces or a hydrophilic coating, such as a biofilm. The attachment of air bubbles is often a nuisance for marine organisms, because such bubbles cause unfavorable buoyancy and form an obstructive barrier against transport of water-soluble molecules. Figure 3 shows the waterwettability and oil-wettability of some seagrasses and seaweeds inhabiting in the intertidal zone. While a glass (cover slip) without any coatings is a moderately hydrophilic material, the seagrass and seaweeds are also hydrophilic and lipophobic. In some species, mucus exuded from organisms may enhance their hydrophilicity and lipophobicity.
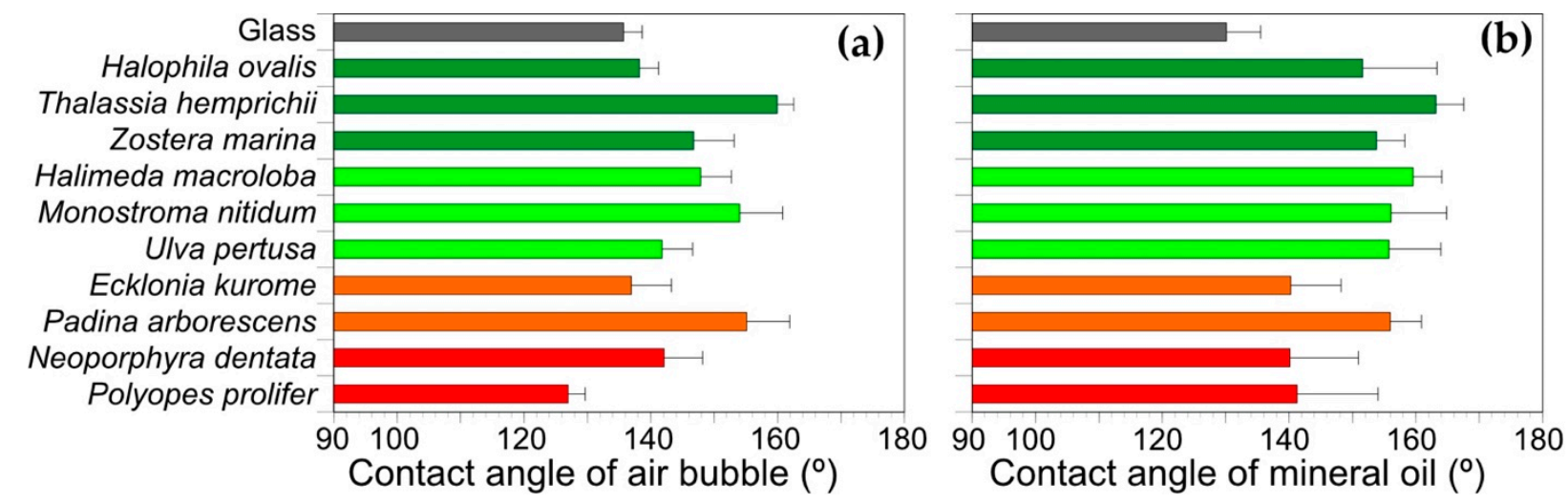

Figure 3. Contact angles of water droplets (a) and mineral oil (b) on glass (gray), seagrass (green), green alga (yellow green), brown alga (brown), and red alga (red). Fifteen to twenty measurements were carried out for each species in seawater (see Figure $2 b, c)$. Error bars indicate standard deviations.

\subsection{Substrate Preference in Wettability}

Several studies have reported the substrate preferences of larvae in terms of wettability based on single-choice or multiple-choice tests. The settlement rate of ascidian larvae was shown to be greater on more hydrophobic surfaces than on less hydrophobic surfaces in Phallusia nigra (single-choice test) [4] and more larvae attached on more hydrophobic substrates in Ciona intestinalis (multi-choice test) [10]. Similarly, larval settlement rates were greater on hydrophobic substrates in the bryozoan Bugula neritina [3,4,27], and more zoospores attached on more hydrophobic substrates in the green alga Ulva linza [28]. In contrast, settlement rates of pediveligers of the bivalve Mytilus galloprovicialis were greater on hydrophilic substrates [6]. Preferences regarding wettability are different in barnacle species; cyprid larvae of Balanus amphitrite settled in higher percentages on more hydrophilic surfaces [3,4], although cyprids of Balanus improvisus settled in higher percentages on more hydrophobic surfaces [5]. It may be difficult to compare these results simply, because the experimental procedures were different in each study. However, these studies still indicate that larvae or spores of various organisms have settlement preferences in terms of wettability. Comprehensive surveys with a standardized assay are required to clarify the preferences of various species or taxa. 
We carried out quadruple-choice tests for substrate selection of the ascidian larvae of Phallusia philippinensis using nine commercially available materials as substrates with different water- and oil-wettability [11]. We tested seven combinations of substrates in the quadruple-choice test, and, in each test, Manly's resource selection index was calculated from the number of juveniles that settled on each of four substrates. Multiple comparisons of the selection indices showed significant difference in preference among the substrates. The rank of preference was determined for each of the nine substrates by integrating the test results; the ascidian larvae tended to select more hydrophobic/oleophilic substrates for settlement (Figure 4). We suppose that nine (or more) substrates are more than necessary in order to grasp the substrate preferences regarding wettability and propose a simplified quadruple-choice test using silicone rubber, polyvinyl chloride, glass, and SH2CLHF (3M) as a candidate for a standard assay.

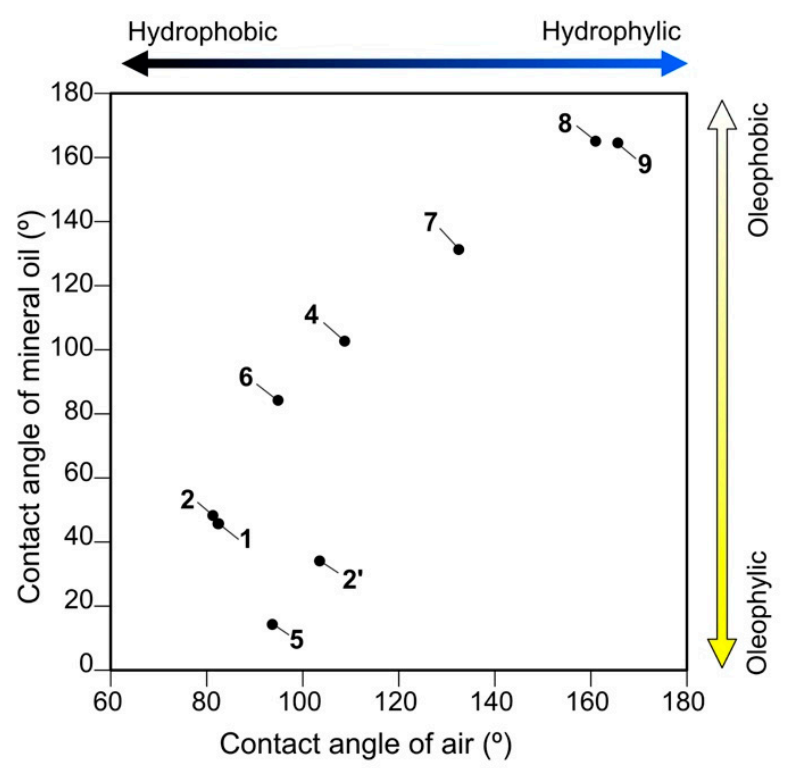

Figure 4. The rank of substrate preference in the settlement of Phallusia philippinensis larvae with water- and oil-wettability (modified from [11]). The numbers indicate the rank of preference with the rank of 2 and $2^{\prime}$ being tied. 1, polytetrafluoroethylene; 2 , silicone rubber; $2^{\prime}$, polyvinylidene chloride; 4, polychlorotrifluoroethylene; 5, Parafilm (Amcor Ltd.); 6, polyvinyl chloride; 7, glass; 8, 1.5\% agar; 9, SH2CLHF (SH: 3M).

Ascidian larvae can detect a small hydrophobic area and settle there. SH2CLHF is a super-hydrophilic material and no larvae settled on the surface. When the SH2CLHF film was slightly cut with a fine surgical knife, a more hydrophobic base film made of polyester was exposed at the cut of less than $50 \mu \mathrm{m}$ in width. On this film, P. philippinensis larvae exclusively attached along the cut line and metamorphosed there (Figure 5). Before settlement, ascidian larvae crawled about on the substrate, with their sensory adhesive organs touching the substrate [23]. It is possible that the larvae sensed the properties of the substrate surface with their adhesive organs and carefully selected the site for settlement.

\section{3. "Silicone Paradox"}

The larvae of ascidians and bryozoans select hydrophobic substrates for settlement, as mentioned above. However, this preference appears inconsistent with the fact that hydrophobic materials, such as silicones, are often used for antifouling on ship hulls and fishing nets. Although silicone rubber ranks second in Figure 4, silicones are also regarded as effective compounds to reduce fouling [29-32]. Zhang et al. [1] reported that superhydrophobic surfaces showed fouling repellency for a few weeks but subsequently lost anti-fouling properties in months. Moreover, the adhesion strength of barnacles on silicone was significantly smaller than that on epoxy resin as a control [33]. In another 
study, more sporelings of the green alga Ulva were detached from hydrophobic surfaces, while diatom Navicula cells were more easily detached from hydrophilic surfaces [34]. Thus, some larvae clearly select hydrophobic surfaces that generally show fouling repellency, and this is called the "silicone paradox."

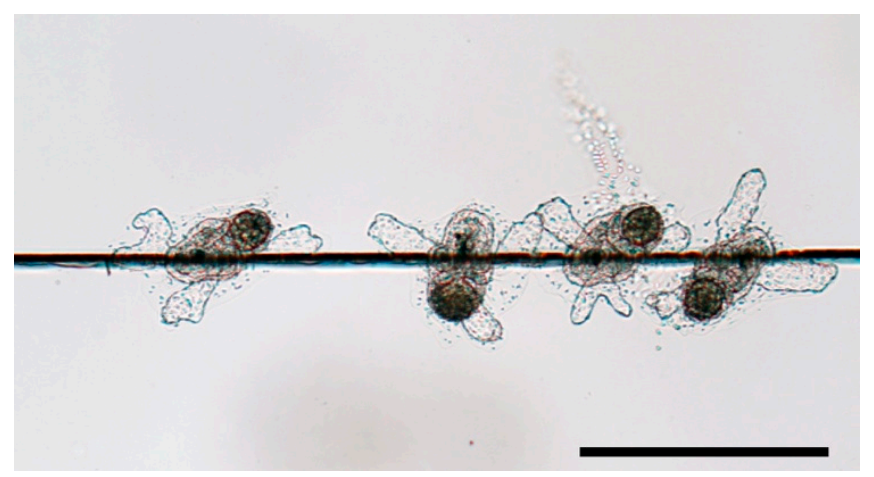

Figure 5. Phallusia philippinensis larvae settling exclusively on the cut line of a SH2CLHF film. Scale bar $1 \mathrm{~mm}$.

Considering the low adhesion strength on hydrophobic surfaces, the fouling repellency of silicone probably results from post-settlement selection. On the other hand, the larval preference to hydrophobic surfaces as shown in laboratory experiments is pre-settlement selection of substrate. Therefore, pre-settlement selection favors hydrophobic surfaces, but the settlers have larger risks to be eliminated on more hydrophobic substrates by postsettlement selection. The preference to hydrophobic surfaces appears to be less adaptive for survival, and thus, it is difficult to explain why this preference occurs from an adaptive evolutionary viewpoint.

We think that the preference to hydrophobic surfaces in ascidians does not result from the adaptation to find better sites for settlement, but from a physicochemical mechanism such as an affinity with adhesive compounds secreted from the adhesive organs. In the initial phase of adhesion to a substrate, the larvae touch the substrate with the tips of the adhesive organs. When the larva is detached from the substrate, secreted material remains on the substrate surface in the manner of footprints [10]. If the adhesion strength of the secreted material is higher on hydrophobic surfaces, more larvae will settle on hydrophobic surfaces. After settlement, ascidian juveniles adhere to the substrate via the tunic, but the adhesion strength of the tunic might be lower on hydrophobic surfaces. In an aquatic environment, natural surfaces are usually hydrophilic (e.g., Figure 3), and thus, larvae settle on moderately hydrophilic substrates. For marine organisms, hydrophobic substrates may be almost an unexperienced surface in their evolutionary history, and thus, they have not yet adapted to hydrophobic surfaces even if such a surface is not suitable for post-settlement selection. It will be important to investigate the adhesion mechanism between substrates and the glue secreted from the adhesive organs for proving an answer to this paradox.

\section{Surface Structures}

\subsection{Preference in Surface Structure}

Natural substrates often have uneven surfaces, and even artificial, flat substrates may have some roughness at the microscopic level. Several studies have indicated that larval preference depends on the size of the structure. The $400-\mu \mathrm{m}$ texture on a hydrophobic substrate much enhanced the settlement of Mytilus pediveligers [6], and ascidian larvae of $C$. intestinalis and Botrylloides violaceus prefer rougher surfaces [9]. In contrast to these micro-scale structures, nano-scale roughness on hydrophobic materials generates a superhydrophobic surface that show anti-fouling properties against a broad spectrum of settlers including algal cells, algal spores, bryozoans, and barnacles [7]. For a better understanding 
of effective structures to prevent biofouling, surface structures of marine organisms have recently been focused on as biomimetic models for fouling control [35].

\subsection{Nano-Scale Nipple Array}

The moth-eye structure, or nano-scale nipple array, was originally discovered on the cornea of the compound eye in nocturnal moths [36]. This structure is an array of nipple-shaped protuberances of about $100 \mathrm{~nm}$ or less in height, and is well known to reduce light reflection on the surface, i.e., the moth-eye effect, by forming a gradient of refractivity [36,37]. This lower reflection simultaneously indicates higher transmission of light into the eyes. This is also an advantage in low-light conditions, and comparative studies of nocturnal and diurnal lepidopterans have suggested that greater transmission of UV light from the moth-eye structure may be important for lepidopterans and cause attraction to UV lights [38]. Moreover, some other functions have been demonstrated for this structure. The nipple array of some insects reduces adhesion and water wettability, and this property prevents dust and dew from adhering to the surface [39,40]. A bactericidal property was shown in the nipple array of black silicon, a synthetic material, as well as those on cicada and dragonfly wings [41,42]. Thus, the nipple array can be regarded as a multifunctional structure.

The nipple array has been also found from body surfaces of marine invertebrates belonging to various taxa, such as ascidians [43-45], salps [46-48], endoparasitic copepods [49], echinoderms [50,51], annelids [52], and entoprocts [53]. The histological bases of these nano-structures are different among taxa; the nipple-like protuberances are formed with cellulosic, integumentary matrix (tunic) in tunicates, chitinous exoskeleton in copepods, and microvilli in entoprocts, indicating the functional importance of this structure and its convergent occurrence in the evolutionary history of metazoans. On the other hand, a nipple array does not always occur within some taxa. For instance, nipple arrays were found in the species of some ascidian families (e.g., Polyclinidae and Styelidae) but not in other families (e.g., Didemnidae and Ascidiidae) [45], and, in salps, the nano-structure has only been reported in species that occur at shallow depths in daytime [47]. This suggests that the importance of this functional structure depends on the habitat and lifestyle of the species.

An anti-reflection effect in water certainly exists but is not as great as what was found in the air, as the reflectance of animal body surfaces is naturally small in water due to the small differences of refractive indices between seawater and animal tissue $[47,54,55]$. Furthermore, synthetic materials mimicking the nipple array have enabled us to evaluate potential functions other than anti-reflection in aquatic conditions; hydrophilic, nano-scale nipple arrays significantly reduce the attachment of air bubbles [56] and suppress cell attachment and phagocytic activity on the structure $[57,58]$. Thus, the nipple array seems to be a multifunctional structure in water, and may have a significant effect on the fouling of animal body surfaces.

\subsection{Settlement Test on Synthetic Nipple Array}

MOSMITE $^{\mathrm{TM}}$ is a synthetic film for anti-reflection that namely mimics the moth-eye structure [59], with a nano-structure made of acrylic resin coating a base film made of polyethylene terephthalate. To evaluate whether the nipple array affects the substrate preference of ascidian larvae, we performed a dual-choice test with P. philippinensis larvae using MOSMITE ${ }^{\mathrm{TM}}$ and a flat film made of the same material, i.e., the base film coated with acrylic resin, as control [8]. The ascidian larvae significantly preferred the flat surface to MOSMITE ${ }^{\mathrm{TM}}$ for settlement. One of the reasons for this preference is the difference in wettability; MOSMITE ${ }^{\mathrm{TM}}$ is more hydrophilic than the flat surface. On the sheets of the same dimension, the surface area of MOSMITE ${ }^{\mathrm{TM}}$ is much larger than that of the flat sheet, due to the nano-structures. Under a homogeneous wetting regime, i.e., Wentzel state, a larger surface area enhances the water wettability on a hydrophilic material [60]. 
Accordingly, MOSMITE ${ }^{\mathrm{TM}}$ is more hydrophilic than the flat sheet, even though the surface material is the same in both sheets.

At the beginning of ascidian settlement, the adhesive organs secrete adhesive compounds to attach to the substrate surface $[61,62]$. On MOSMITE ${ }^{\mathrm{TM}}$, the adhesive compound penetrates into the nipple array layer and fills the space among the nipple-like protuberances, whereas the compound simply spread over the flat surface (Figure $6 a, b)$. The adhesion strength on MOSMITE ${ }^{\mathrm{TM}}$ is, thus, likely greater than the strength on the flat surface, due to the larger surface area for adhesion. This appears inconsistent with the substrate preference for flat surfaces to MOSMITE ${ }^{\mathrm{TM}}$. Following metamorphosis, juveniles extend the epidermal ampullae and hold fast to the substrate via tunic (Figures 1c and 5), and the tunic surface is always overlaid with a cuticular, electron-dense layer. On MOSMITE ${ }^{\mathrm{TM}}$, the tunic cuticle adheres to the tip of the nipples only, with the space in the nipple array layer remaining vacant (blue area in Figure $6 c$ ), whereas the cuticle covers the flat surface entirely (Figure 6d). Therefore, the settlers on MOSMITE ${ }^{\mathrm{TM}}$ would be more easily detached from the substrate than settlers on the flat surface in post-settlement selection. From the viewpoint of evolutionary adaptation, the larvae may have a mechanism to avoid settlement on nano-scale nipple arrays. How can larvae sense nano-structures on substrate surfaces? As mentioned above, natural substrata in an aquatic environment are generally hydrophilic, and, on a hydrophilic material, surfaces with nano-structures are more hydrophilic than flat surfaces. If ascidian larvae select less hydrophilic sites for settlement, they may be able to avoid settlement on nano-structures. This idea can be one of possible explanations for the preference for hydrophobic surfaces causing the silicone paradox.
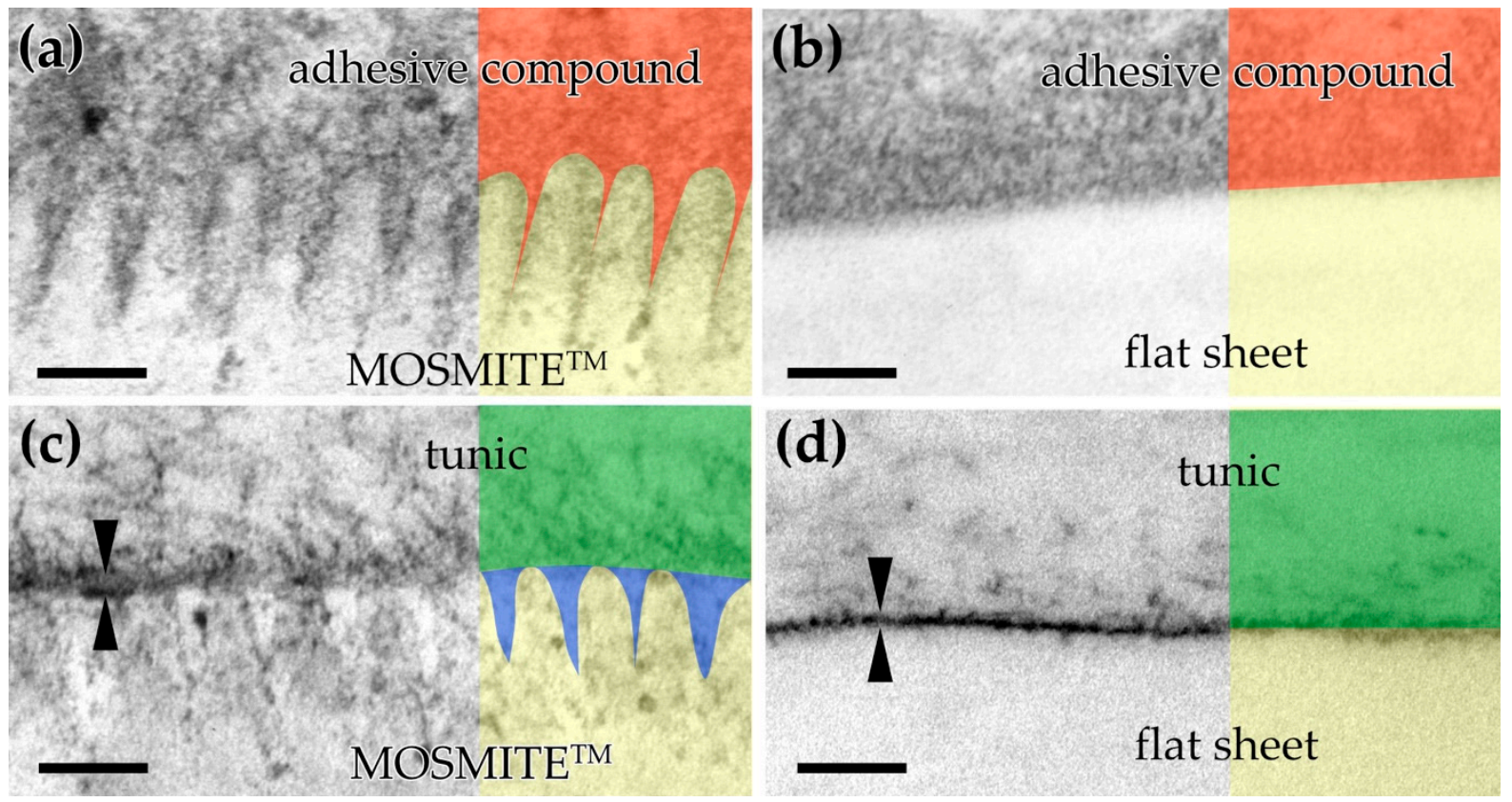

Figure 6. Electron micrographs of the adhesion point between the substrate (yellow) and adhesive compound (red) or tunic (green) in the settlement of Phallusia philippinensis. (a) Adhesive compound on MOSMITE ${ }^{\mathrm{TM}}$. (b) Adhesive compound on flat sheet. (c) Tunic on MOSMITE ${ }^{\mathrm{TM}}$. Vacant space remains between the nipple array layer (blue). (d) Tunic on flat sheet. Facing arrowheads indicate tunic cuticle. Scale bars $100 \mathrm{~nm}$.

\section{Flypapers May Mitigate Invasive Fouling}

Humanity has built, left, or abandoned various artificial structures in the water, including aquaculture facilities and ship hulls as well as ports and seawalls. Artificial structures provide huge areas of a novel microenvironment which marine organisms had never experienced, and some 'winner' species may thrive on these structures. The winner is often a non-indigenous species, causing serious ecological and economic problems, and artificial 
structures are also a base for the dispersal for non-native, invasive species [63-65]. Many studies have focused on anti-fouling properties, i.e., which substrates are comparatively less fouled and what compounds suppress biofouling. Larval preferences of substrata should also be important to gain a better understanding of the biological processes of settlement, and preference data can be useful in controlling fouling.

Settlers are very often nuisances in aquaculture. They are competitors against the cultured organisms, such as shellfish, for space and food resources, and they often fill up the opening of cages and nets. Moreover, workers have to remove settlers on cultured organisms at harvest. Chemical approaches, i.e., anti-fouling compounds, potentially cause environmental pollution and damage native biota [66-71]. Physical approaches provide less effective but safer countermeasures against fouling of non-indigenous species. Hand elimination of a particular species is the most eco-friendly method but requires a large labor force. We hypothetically propose the use of hydrophobic substrates as a 'flypaper' for settlers. As discussed in this review, the larvae of ascidians and some other invertebrates significantly select more hydrophobic substrates for settlement. If hydrophobic substrates, such as ropes or belts of silicone, are hung nearby aquaculture facilities in the settlement seasons of target species, many larvae can be expected to settle on these hydrophobic substrates. Subsequently, the hydrophobic substrates can be removed from the water and dried/washed to remove settlers. Then, the substrates can be placed in the water again. Of course, this method is effective for the settlers preferring hydrophobic substrates, such as ascidians, and does not radically eliminate the settlers but probably will mitigate the impact of biofouling with a need for less of a labor force than hand elimination. Some settlers would be spontaneously detached from the substrate in post-settlement selection due to weak adhesive strength on hydrophobic surfaces. These detached settlers likely would die on the sea bottom, as they cannot swim after metamorphosis. Moreover, nano-structures on hydrophobic surfaces are expected to enhance the flypaper effect, i.e., attraction and spontaneous detachment of settlers. Theoretically, nano-structures on hydrophobic surfaces reduce water-wettability, and the adhesion strengths are also much reduced due to the smaller adhesion area for settlers, as found in Figure 6c. Even if such a physical approach cannot show enough effect practically, its use combined with chemical approaches may reduce the effective concentrations of antifouling compounds. Currently, this is no more than a plan on paper but it indicates the importance of studies on the mechanisms of substrate selection in fouling organisms.

Author Contributions: E.H. prepared the draft. N.S. provided some figure data. Both authors have read and agreed to the published version of the manuscript.

Funding: This research received no external funding.

Institutional Review Board Statement: This work complies with the ethical guidelines of University of the Ryukyus Animal Experimentation Committee.

Informed Consent Statement: Not applicable.

Data Availability Statement: Not applicable.

Acknowledgments: We are grateful to the special issue editor, Francesca Cima, for providing the opportunity to contribute this review. We thank Mitsubishi Chemical Corporation for generously providing the MOSMITE ${ }^{\mathrm{TM}}$ and the flat film. Our thanks also to James Davis Reimer for peerreviewing and editing the manuscript.

Conflicts of Interest: The authors declare no conflict of interest.

\section{References}

1. Zhang, H.; Lamb, R.; Lewis, J. Engineering nanoscale roughness on hydrophobic surface-Preliminary assessment of fouling behaviour. Sci. Technol. Adv. Mater. 2005, 6, 236-239. [CrossRef]

2. Siddik, A.A.; Al-Sofyani, A.A.; Ba-Akdah, M.A.; Satheesh, S. Invertebrate recruitment on artificial substrates in the Red Sea: Role of substrate type and orientation. J. Mar. Biol. Assoc. U. K. 2019, 99, 741-750. [CrossRef] 
3. Rittschof, D.; Costlow, J.D. Bryozoan and barnacle settlement in relation to initial surface wettability: A comparison of laboratory and field studies. Sci. Mar. 1989, 53, 411-416.

4. Gerhart, D.J.; Rittschof, D.; Hooper, I.R.; Eisenman, K.; Meyer, A.E.; Baier, R.E.; Young, C. Rapid and inexpensive quantifications of the combined polar components of surface wettability application to biofouling. Biofouling 1992, 5, 251-259. [CrossRef]

5. Dahlström, M.; Jonsson, H.; Jonsson, P.R.; Elwing, H. Surface wettability as a determinant in the settlement of the barnacle Balanus Improvisus (DARWIN). J. Exp. Mar. Bio. Ecol. 2004, 305, 223-232. [CrossRef]

6. Carl, C.; Poole, A.J.; Sexton, B.A.; Glenn, F.L.; Vucko, M.J.; Williams, M.R.; Whalan, S.; de Nys, R. Enhancing the settlement and attachment strength of pediveligers of Mytilus galloprovincialis by changing surface wettability and microtopography. Biofouling 2012, 28, 175-186. [CrossRef]

7. Scardino, A.J.; Zhang, H.; Cookson, D.J.; Lamb, R.N.; de Nys, R. The role of nano-roughness in antifouling. Biofouling 2009, 25, 757-767. [CrossRef]

8. Hirose, E.; Sensui, N. Does a nano-scale nipple array (moth-eye structure) suppress the settlement of ascidian larvae? J. Mar. Biol. Assoc. U. K. 2019, 99, 1393-1397. [CrossRef]

9. Chase, A.L.; Dijkstra, J.A.; Harris, L.G. The influence of substrate material on ascidian larval settlement. Mar. Pollut. Bull. 2016, 106, 35-42. [CrossRef]

10. Zeng, F.; Wunderer, J.; Salvenmoser, W.; Ederth, T.; Rothbächer, U. Identifying adhesive components in a model tunicate. Philos. Trans. R. Soc. B Biol. Sci. 2019, 374, 20190197. [CrossRef]

11. Sensui, N.; Hirose, E. Wettability and substrate selection in the larval settlement of the solitary ascidian Phallusia philippinensis (Phlebobranchia: Ascidiidae). Zool. Sci. 2020, 37, 366-370. [CrossRef]

12. Matsunobu, S.; Sasakura, Y. Time course for tail regression during metamorphosis of the ascidian Ciona intestinalis. Dev. Biol. 2015, 405, 71-81. [CrossRef]

13. Bannister, J.; Sievers, M.; Bush, F.; Bloecher, N. Biofouling in marine aquaculture: A review of recent research and developments. Biofouling 2019, 35, 631-648. [CrossRef] [PubMed]

14. Chambers, L.D.; Stokes, K.R.; Walsh, F.C.; Wood, R.J.K. Modern approaches to marine antifouling coatings. Surf. Coat. Technol. 2006, 201, 3642-3652. [CrossRef]

15. Turner, A. Marine pollution from antifouling paint particles. Mar. Pollut. Bull. 2010, 60, 159-171. [CrossRef] [PubMed]

16. Lawes, J.C.; Clark, G.F.; Johnston, E.L. Disentangling settlement responses to nutrient-rich contaminants: Elevated nutrients impact marine invertebrate recruitment via water-borne and substrate-bound cues. Sci. Total Environ. 2018, 645, 984-992. [CrossRef] [PubMed]

17. Lambert, G. Ecology and natural history of the protochordates. Can. J. Zool. 2005, 83, 34-50. [CrossRef]

18. Hirose, E. Ascidian tunic cells: Morphology and functional diversity of free cells outside the epidermis. Invertebr. Biol. 2009, 128, 83-96. [CrossRef]

19. Burighel, P.; Cloney, R.A. Urochordata: Ascidiacea. In Microscopic Anatomy of Invertebrates Hemichordata, Chaetognatha, and the Invertebrate Chordates; Harrison, F.W., Ruppert, E., Eds.; Wiley-Liss, Inc.: New York, NY, USA, 1997; Volume 15, pp. $221-347$. ISBN 0471561223.

20. Huber, J.L.; da Silva, K.B.; Bates, W.R.; Swalla, B.J. The evolution of anural larvae in molgulid ascidians. Semin. Cell Dev. Biol. 2000, 11, 419-426. [CrossRef]

21. Tsuda, M.; Sakurai, D.; Goda, M. Direct evidence for the role of pigment cells in the brain of ascidian larvae by laser ablation. J. Exp. Biol. 2003, 206, 1409-1417. [CrossRef] [PubMed]

22. Bingham, B.L.; Reyns, N.B. Ultraviolet radiation and distribution of the solitary ascidian Corella inflata (Huntsman). Biol. Bull. 1999, 196, 94-104. [CrossRef]

23. Zeng, F.; Wunderer, J.; Salvenmoser, W.; Hess, M.W.; Ladurner, P.; Rothbächer, U. Papillae revisited and the nature of the adhesive secreting collocytes. Dev. Biol. 2019, 448, 183-198. [CrossRef] [PubMed]

24. Hadfield, M.; Paul, V. Natural chemical cues for settlement and metamorphosis of marine-invertebrate larvae. In Marine Chemical Ecology; McClintock, J.B., Baker, B.J., Eds.; CRC Press: Cambridge, UK, 2001; pp. 431-461. ISBN 9781420036602.

25. Tsukamoto, S.; Kato, H.; Hirota, H.; Fusetani, N. Lumichrome. A larval metamorphosis-inducing substance in the ascidian Halocynthia roretzi. Eur. J. Biochem. 1999, 264, 785-789. [CrossRef] [PubMed]

26. Grosberg, R.K.; Quinn, J.F. The genetic control and consequences of kin recognition by the larvae of a colonial marine invertebrate. Nature 1986, 322, 456-459. [CrossRef]

27. Mihm, J.W.; Banta, W.C.; Loeb, G.I. Effects of adsorbed organic and primary fouling films on bryozoan settlement. J. Exp. Mar. Biol. Ecol. 1981, 54, 167-179. [CrossRef]

28. Callow, M.E.; Callow, J.A.; Ista, L.K.; Coleman, S.E.; Nolasco, A.C.; Lopez, G.P. Use of self-assembled monolayers of different wettabilities to study surface selection and primary adhesion processes of green algal (Enteromorpha) zoospores. Appl. Environ. Microbiol. 2000, 66, 3249-3254. [CrossRef]

29. Hodson, S.L.; Burke, C.M.; Bissett, A.P. Biofouling of fish-cage netting: The efficacy of a silicone coating and the effect of netting colour. Aquaculture 2000, 184, 277-290. [CrossRef]

30. Terlizzi, A.; Conte, E.; Zupo, V.; Mazzella, L. Biological succession on silicone fouling-release surfaces: Long-term exposure tests in the Harbour of Ischia, Italy. Biofouling 2000, 15, 327-342. [CrossRef] 
31. Tettelbach, S.T.; Tetrault, K.; Carroll, J. Efficacy of Netminder ${ }^{\circledR}$ silicone release coating for biofouling reduction in bay scallop grow-out and comparative effects on scallop survival, growth and reproduction. Aquac. Res. 2014, 45, 234-242. [CrossRef]

32. Flemming, H.C. Biofouling in water systems-Cases, causes and countermeasures. Appl. Microbiol. Biotechnol. 2002, 59, 629-640. [CrossRef]

33. Swain, G.W.; Schultz, M.P. The testing and evaluation of non-toxic antifouling coatings. Biofouling 1996, 10, 187-197. [CrossRef]

34. Krishnan, S.; Wang, N.; Ober, C.K.; Finlay, J.A.; Callow, M.E.; Callow, J.A.; Hexemer, A.; Sohn, K.E.; Kramer, E.J.; Fischer, D.A. Comparison of the fouling release properties of hydrophobic fluorinated and hydrophilic PEGylated block copolymer surfaces: Attachment strength of the diatom Navicula and the green alga Ulva. Biomacromolecules 2006, 7, 1449-1462. [CrossRef] [PubMed]

35. Scardino, A.J.; de Nys, R. Mini review: Biomimetic models and bioinspired surfaces for fouling control. Biofouling 2011, 27, 73-86. [CrossRef]

36. Bernhard, C.G. Structural and functional adaptation in a visual system. Endeavour 1967, 26, 79-84.

37. Wilson, S.J.; Hutley, M.C. The optical properties of "moth eye" antireflection surfaces. Opt. Acta 1982, 29, 993-1009. [CrossRef]

38. Spalding, A.; Shanks, K.; Bennie, J.; Potter, U.; Ffrench-Constant, R. Optical modelling and phylogenetic analysis provide in butterflies and moths. Insects 2019, 10, 262. [CrossRef] [PubMed]

39. Watson, G.S.; Myhra, S.; Cribb, B.W.; Watson, J.A. Putative functions and functional efficiency of ordered cuticular nanoarrays on insect wings. Biophys. J. 2008, 94, 3352-3360. [CrossRef]

40. Peisker, H.; Gorb, S.N. Always on the bright side of life: Anti-adhesive properties of insect ommatidia grating. J. Exp. Biol. 2010, 213, 3457-3462. [CrossRef]

41. Ivanova, E.P.; Hasan, J.; Webb, H.K.; Truong, V.K.; Watson, G.S.; Watson, J.A.; Baulin, V.A.; Pogodin, S.; Wang, J.Y.; Tobin, M.J.; et al. Natural bactericidal surfaces: Mechanical rupture of Pseudomonas aeruginosa cells by cicada wings. Small 2012, 8, 2489-2494. [CrossRef] [PubMed]

42. Ivanova, E.P.; Hasan, J.; Webb, H.K.; Gervinskas, G.; Juodkazis, S.; Truong, V.K.; Wu, A.H.F.; Lamb, R.N.; Baulin, V.A.; Watson, G.S.; et al. Bactericidal activity of black silicon. Nat. Commun. 2013, 4, 2838. [CrossRef] [PubMed]

43. Hirose, E.; Saito, Y.; Hashimoto, K.; Watanabe, H. Minute protrusions of the cuticle: Fine surface structures of the tunic in ascidians. J. Morphol. 1990, 204, 67-73. [CrossRef]

44. Hirose, E.; Nishikawa, T.; Saito, Y.; Watanabe, H. Minute protrusions of ascidian tunic cuticle: Some implications for ascidian phylogeny. Zool. Sci. 1992, 9, 405-412.

45. Hirose, E.; Lambert, G.; Kusakabe, T.; Nishikawa, T. Tunic cuticular protrusions in ascidians (Chordata, Tunicata): A perspective of their character-state distribution. Zool. Sci. 1997, 14, 683-689. [CrossRef]

46. Hirose, E.; Kimura, S.; Itoh, T.; Nishikawa, J. Tunic morphology and cellulosic components of pyrosomas, doliolids, and salps (Thaliacea, Urochordata). Biol. Bull. 1999, 196, 113-120. [CrossRef]

47. Hirose, E.; Sakai, D.; Shibata, T.; Nishii, J.; Mayama, H.; Miyauchi, A.; Nishikawa, J. Does the tunic nipple array serve to camouflage diurnal salps? J. Mar. Biol. Assoc. U. K. 2015, 95, 1025-1031. [CrossRef]

48. Sakai, D.; Kakiuchida, H.; Nishikawa, J.; Hirose, E. Physical properties of the tunic in the pinkish-brown salp Pegea confoederata (Tunicata: Thaliacea). Zool. Lett. 2018, 4, 7. [CrossRef] [PubMed]

49. Hirose, E.; Uyeno, D. Histopathology of a mesoparasitic hatschekiid copepod in hospite: Does Mihbaicola sakamakii (Copepoda: Siphonostomatoida: Hatschekiidae) fast within the host fish tissue? Zool. Sci. 2014, 31, 546-552. [CrossRef] [PubMed]

50. Holland, N.D.; Nealson, K.H. The fine structure of the echinoderm cuticle and the subcuticular bacteria of echinoderms. Acta Zool. 1978, 59, 169-185. [CrossRef]

51. Flammang, P.; Jangoux, M. Functional morphology of coronal and peristomeal podia in Sphaerechinus granularis (Echinodermata, Echinoida) Patrick. Zoomorphology 1993, 113, 47-60. [CrossRef]

52. Hausen, H. Comparative structure of the epidermis in polychaetes (Annelida). Hydrobiologia 2005, 535-536, 25-35. [CrossRef]

53. Iseto, T.; Hirose, E. Comparative morphology of the foot structure of four genera of Loxosomatidae (Entoprocta): Implications for foot functions and taxonomy. J. Morphol. 2010, 271, 1185-1196. [CrossRef] [PubMed]

54. Kakiuchida, H.; Sakai, D.; Nishikawa, J.; Hirose, E. Measurement of refractive indices of tunicates' tunics: Light reflection of the transparent integuments in an ascidian Rhopalaea sp. and a salp Thetys vagina. Zool. Lett. 2017, 3, 7. [CrossRef] [PubMed]

55. Sakai, D.; Kakiuchida, H.; Harada, K.; Nishikawa, J.; Hirose, E. Parallel plications may enhance surface function: Physical properties of transparent tunics in colonial ascidians Clavelina cyclus and C. obesa. J. Mar. Biol. Assoc. U. K. 2019, 99, 1831-1839. [CrossRef]

56. Hirose, E.; Mayama, H.; Miyauchi, A. Does the aquatic invertebrate nipple array prevent bubble adhesion? An experiment using nanopillar sheets. Biol. Lett. 2013, 9, 20130552. [CrossRef] [PubMed]

57. Nomura, S.; Kojima, H.; Ohyabu, Y.; Kuwabara, K.; Miyauchi, A.; Uemura, T. Cell culture on nanopillar sheet: Study of HeLa cells on nanopillar sheet. Jpn. J. Appl. Phys. 2005, 44, 1184-1186. [CrossRef]

58. Ballarin, L.; Franchi, N.; Gasparini, F.; Caicci, F.; Miyauchi, A.; Hirose, E. Suppression of cell-spreading and phagocytic activity on nano-pillared surface: In vitro experiment using hemocytes of the colonial ascidian Botryllus schlosseri. Invertebr. Surviv. J. 2015, $12,82-88$.

59. Moth Eyes High-Performance Film MOSMITETM. Available online: https:/ /www.m-chemical.co.jp/en/products/departments / mcc/hp-films-pl/product/1201267_7568.html (accessed on 11 April 2021).

60. Marmur, A. Wetting on hydrophobic rough surfaces: To be heterogeneous or not to be? Langmuir 2003, 19, 8343-8348. [CrossRef] 
61. Cloney, R.A. Ascidian larvae and the events of metamorphosis. Am. Zool. 1982, 22, 817-826. [CrossRef]

62. Karaiskou, A.; Swalla, B.J.; Sasakura, Y.; Chambon, J. Metamorphosis in solitary ascidians. Genesis 2015, 47, 34-47. [CrossRef] [PubMed]

63. Simkanin, C.; Davidson, I.C.; Dower, J.F.; Jamieson, G.; Therriault, T.W. Anthropogenic structures and the infiltration of natural benthos by invasive ascidians. Mar. Ecol. Prog. Ser. 2012, 33, 499-511. [CrossRef]

64. Airoldi, L.; Turon, X.; Perkol-Finkel, S.; Rius, M.; Keller, R. Corridors for aliens but not for natives: Effects of marine urban sprawl at a regional scale. Divers. Distrib. 2015, 21, 755-768. [CrossRef]

65. Aldred, N.; Clare, A.S. Mini-review: Impact and dynamics of surface fouling by solitary and compound ascidians. Biofouling 2014, 30, 259-270. [CrossRef] [PubMed]

66. Cima, F.; Bragadin, M.; Ballarin, L. Toxic effects of new antifouling compounds on tunicate haemocytes I. Sea-nine 211 and chlorothalonil. Aquat. Toxicol. 2008, 86, 299-312. [CrossRef] [PubMed]

67. Menin, A.; Ballarin, L.; Bragadin, M.; Cima, F. Immunotoxicity in ascidians: Antifouling compounds alternative to organotins-II. The case of Diuron and TCMS pyridine. J. Environ. Sci. Health Part B 2008, 43, 644-654. [CrossRef] [PubMed]

68. Cima, F.; Ballarin, L. Immunotoxicity in ascidians: Antifouling compounds alternative to organotins: III-The case of copper(I) and Irgarol 1051. Chemosphere 2012, 89, 19-29. [CrossRef]

69. Cima, F.; Ballarin, L. Immunotoxicity in ascidians: Antifouling compounds alternative to organotins-IV. The case of zinc pyrithione. Comp. Biochem. Physiol. C Toxicol. Pharmacol. 2015, 169, 16-24. [CrossRef]

70. Amara, I.; Miled, W.; Ben, R.; Ladhari, N. Antifouling processes and toxicity effects of antifouling paints on marine environment. A review. Environ. Toxicol. Pharmacol. 2018, 57, 115-130. [CrossRef]

71. Cima, F.; Varello, R. Immunotoxicity in ascidians: Antifouling compounds alternative to organotins-V. the case of dichlofluanid. J. Mar. Sci. Eng. 2020, 8, 396. [CrossRef] 